\title{
An efficient nickel hydrogen oxidation catalyst for hydroxide exchange membrane fuel cells
}

\author{
Weiyan $\mathrm{Ni}^{1, \dagger}$, Teng Wang ${ }^{2, \dagger}$, Florent Héroguel ${ }^{3}$, Anna Krammer ${ }^{4}$, Seunghwa Lee $^{1}$, Liang Yao ${ }^{5}$, \\ Andreas Schüler ${ }^{4}$, Jeremy S. Luterbacher ${ }^{3}$, Yushan Yan $^{2, *}$ and Xile $\mathrm{Hu}^{1, *}$
}

\section{Affiliations:}

${ }^{1}$ Laboratory of Inorganic Synthesis and Catalysis, Institute of Chemical Sciences and Engineering, École Polytechnique Fédérale de Lausanne (EPFL), Lausanne CH-1015, Switzerland.

${ }^{2}$ Department of Chemical and Biomolecular Engineering, University of Delaware, Newark, Delaware 19716, USA.

${ }^{3}$ Laboratory of Sustainable and Catalytic Processing, Institute of Chemical Sciences and Engineering, École Polytechnique Fédérale de Lausanne (EPFL), Lausanne CH-1015, Switzerland. ${ }^{4}$ Solar Energy and Building Physics Laboratory, Institute of Civil Engineering, École Polytechnique Fédérale de Lausanne (EPFL), 1015 Lausanne Switzerland.

${ }^{5}$ Laboratory for Molecular Engineering of Optoelectronic Nanomaterials, Institute of Chemical Sciences and Engineering, École Polytechnique Fédérale de Lausanne (EPFL), 1015 Lausanne, Switzerland.

$\dagger$ These authors contributed equally.

Abstract: The hydroxide exchange membrane fuel cell (HEMFC) is a promising energy conversion technology, but it is limited by the need of platinum-group-metal (PGM) electrocatalysts, especially for the hydrogen oxidation reaction (HOR). Here we report a Ni-based HOR catalyst that exhibits an electrochemical surface area-normalized exchange current density of $70 \mu \mathrm{A} / \mathrm{cm}^{2}$, the highest among PGM-free catalysts. The catalyst comprises of Ni nanoparticles embedded in a nitrogen-doped carbon support. According to X-ray and ultraviolet photoelectron spectroscopy as well as $\mathrm{H}_{2}$ chemisorption, the electronic interaction between the Ni nanoparticles and its support leads to an optimal hydrogen binding energy, which is the likely origin of its high activity. PGM-free HEMFCs employing this Ni HOR catalyst give a peak power density of 450 $\mathrm{mW} / \mathrm{cm}^{2}$, up to 6 times higher than previous best-performing analogous. This work demonstrates the feasibility of efficient PGM-free HEMFCs. 
The proton exchange membrane fuel cell (PEMFC) is an emerging clean-energy technology, however, it necessities a heavy usage of Pt catalysts, perfluorinated membranes, and acid-tolerant stack hardware, leading to high cost ${ }^{1}$. The hydroxide exchange membrane fuel cell (HEMFC) is potentially a cost-effective alternative of PEMFC because less costly catalysts, membranes, and stack hardware might be used in alkaline medium. One important target for the development of HEMFC is to become platinum group metal (PGM) free ${ }^{2}$. Currently, PGM-free catalysts for oxygen reduction reaction (ORR) at the cathode have achieved performances comparable to their PGM counterparts ${ }^{3-5}$, and highly conductive and stable hydroxide-exchange membrane has emerged ${ }^{6}$. However, there is a lack of active PGM-free catalysts for the hydrogen oxidation reaction (HOR) at the anode, representing a major barrier for the progress of HEMFCs ${ }^{2,7-10}$. For example, HEMFCs with a PGM HOR catalyst and an Earth-abundant ORR catalyst can reach a peak power density higher than $1300 \mathrm{~mW} / \mathrm{cm}^{25}$, whereas HEMFCs with both PGM-free HOR and ORR catalysts has a highest peak power density of merely $76 \mathrm{~mW} / \mathrm{cm}^{2}{ }^{11}$. As a result, the U.S. Department of Energy (DOE) set a target of $600 \mathrm{~mW} / \mathrm{cm}^{2}$ peak power density for PGM-free HEMFC in $2030^{2}$.

HEMFCs pose challenges for HOR catalysts, not only in having high intrinsic activity, but also in exhibiting other desirable properties such as a large surface area, porous structure, and resistance to high temperature, anodic potential, and $\mathrm{CO}$ poisoning ${ }^{1}$. Among Earth-abundant metals, nickel proves to be the best candidate to meet these requirements. Nevertheless, the state-of-the-art $\mathrm{Ni}$ 20 catalysts typically exhibit intrinsic activity below $40 \mu \mathrm{A} / \mathrm{cm}^{2}{ }_{\text {cat }}{ }^{12-14}$. Although a few catalysts have higher intrinsic activity, their surface areas are very small ${ }^{15,16}$. While some catalysts exhibit good mass activity in model studies using rotating disc electrode (RDE) measurements, they are prone to oxidation and are unsuitable for practical devices ${ }^{17}$. In fact, the stability of nickel in a fuel cell working environment, i.e., at elevated temperature and large current density, has not been well demonstrated. As a result, previously reported $\mathrm{Ni}$ catalysts cannot be translated to good performance in a complete cell configuration, especially with a PGM-free cathode. Here we report a Ni catalyst that exhibits an intrinsic activity of $70 \mu \mathrm{A} / \mathrm{cm}^{2}{ }_{\mathrm{Ni}}$. PGM-free HEMFCs employing this catalyst give a peak power density of $450 \mathrm{~mW} / \mathrm{cm}^{2}$, up to 6 times higher than the best previous analogous. The superior activity of our catalyst is due to an optimized hydrogen binding energy (HBE), resulting from a fine-tuned $\mathrm{Ni}$-support interaction.

The catalyst $\mathrm{Ni}-\mathrm{H}_{2}-\mathrm{NH}_{3}$ was prepared by pyrolyzing a $\mathrm{Ni}$-based $\mathrm{MOF}, \mathrm{Ni}_{3}(\mathrm{BTC})_{2}(\mathrm{BTC}=$ benzene-1,3,5-tricarboxylic acid) ${ }^{17}$, at $390{ }^{\circ} \mathrm{C}$ in a mixed atmosphere of $\mathrm{H}_{2}: \mathrm{NH}_{3}: \mathrm{N}_{2}=$ 4.6\%:33.6\%:61.8\% (v:v:v) (fig. $\mathrm{S} 1$ ). $\mathrm{NH}_{3}$ was used to introduce nitrogen doping to regulate the electronic structure of $\mathrm{Ni}^{12}$, while $\mathrm{H}_{2}$ was used as a reducing agent to form metallic Ni. The temperature and partial pressure of each gas were carefully optimized. Reference compounds $\mathrm{Ni}$ $\mathrm{H}_{2}$ and $\mathrm{Ni}-\mathrm{NH}_{3}$ were prepared using the same method but replacing $\mathrm{NH}_{3}$ and $\mathrm{H}_{2}$ with $\mathrm{N}_{2}$, respectively (fig. 1A).

Transmission electron microscopy (TEM) showed that $\mathrm{Ni}_{2}-\mathrm{H}_{2}-\mathrm{NH}_{3}$ and $\mathrm{Ni}-\mathrm{NH}_{3}$ contained separated, small nanoparticles with an average size of $13.3 \pm 3.5 \mathrm{~nm}$ and $8.6 \pm 2.1 \mathrm{~nm}$, respectively, 
while $\mathrm{Ni}-\mathrm{H}_{2}$ was composed of sintered particles with a large grain size (fig. 1, B to D and fig. S2). Magnified TEM image showed the nickel nanoparticles were surrounded by thin carbon layers in $\mathrm{Ni}-\mathrm{H}_{2}-\mathrm{NH}_{3}$ (fig. S3). After etching of Ni nanoparticles by hydrochloric acid, nano-sized open cavities were observed, suggesting that the Ni nanoparticles were partially embedded in the carbon matrix (fig. S4). Similar features were observed for $\mathrm{Ni}_{-} \mathrm{NH}_{3}$ and $\mathrm{Ni}-\mathrm{H}_{2}$ (fig. S4). High-resolution transmission electron microscopy (HRTEM) revealed the polycrystalline nature of $\mathrm{Ni}^{-} \mathrm{H}_{2}-\mathrm{NH}_{3}$ nanoparticles, which were composed of tiny single crystals (fig. S5). Energy-dispersive X-ray spectroscopy indicated the presence of $\mathrm{Ni}, \mathrm{C}$ and $\mathrm{N}$ in $\mathrm{Ni}-\mathrm{H}_{2}-\mathrm{NH}_{3}$ (fig. S6).

The nickel content was $83.0 \%, 82.6 \%$, and $89.9 \%$ for $\mathrm{Ni}-\mathrm{H}_{2}-\mathrm{NH}_{3}, \mathrm{Ni}-\mathrm{NH}_{3}$, and $\mathrm{Ni}-\mathrm{H}_{2}$, respectively, according to thermogravimetric analysis (fig. S7). According to elemental analysis, $\mathrm{Ni}-\mathrm{H}_{2}-\mathrm{NH}_{3}$, $\mathrm{Ni}-\mathrm{NH}_{3}$ but not Ni- $\mathrm{H}_{2}$ contained nitrogen (Table $\mathrm{S1}$ ). The C:N ratio is 6:1 in $\mathrm{Ni}-\mathrm{H}_{2}-\mathrm{NH}_{3}$ and 2:1 in $\mathrm{Ni}-\mathrm{NH}_{3}$. X-ray diffraction (XRD) patterns of $\mathrm{Ni}-\mathrm{H}_{2}-\mathrm{NH}_{3}, \mathrm{Ni}-\mathrm{NH}_{3}$, and $\mathrm{Ni}-\mathrm{H}_{2}$ revealed metallic nickel as the only crystalline component of these three compounds (fig. 1E). High-resolution $\mathrm{Ni}$ $2 p_{3 / 2}$ X-ray photoelectron spectroscopy (XPS) spectra of all three compounds exhibited two main peaks at around $852.8 \mathrm{eV}$ and $855.3 \mathrm{eV}$, which were attributed to $\mathrm{Ni}(0)$ and surface $\mathrm{Ni}$ (II) oxide, respectively (Fig. 1f). Compared to the $\mathrm{Ni}(0)$ peak of a bulk, unsupported $\mathrm{Ni}$, the $\mathrm{Ni}(0)$ XPS peaks of the three compounds had higher binding energies, indicative of an interfacial charge transfer from $\mathrm{Ni}$ to the carbon support ${ }^{18}$. In addition, $\mathrm{N} 1 \mathrm{~s}$ XPS signals were detected for $\mathrm{Ni}-\mathrm{H}_{2}-\mathrm{NH}_{3}$ and $\mathrm{Ni}-\mathrm{NH}_{3}$, but not for $\mathrm{Ni}-\mathrm{H}_{2}$. All samples had intense C 1s XPS signals (fig. S8). All three compounds exhibited D and G bands in their Raman spectra (fig. 1G), The spectra could be deconvoluted into four peaks, i.e., D1, D3, D4, and G bands (supplementary text, SM). By comparing the intensity ratios of different Raman bands, we concluded that $\mathrm{Ni}^{-\mathrm{NH}_{3}}$ had a more disordered carbon support than $\mathrm{Ni}-\mathrm{H}_{2}-\mathrm{NH}_{3}$ and $\mathrm{Ni}-\mathrm{H}_{2}$ (Table $\mathrm{S} 2$ ). This conclusion was supported by HRTEM images which showed lattice fringes of carbon support for $\mathrm{Ni}-\mathrm{H}_{2}-\mathrm{NH}_{3}$ and $\mathrm{Ni}-\mathrm{H}_{2}$, but not for $\mathrm{Ni}_{-} \mathrm{NH}_{3}$ (fig. S9). Disordered carbon might lead to a lower conductivity. Indeed, four-probe electrical conductivity measurements revealed that $\mathrm{Ni}^{-\mathrm{NH}_{3}}$ had a sheet resistance one order of magnitude higher than $\mathrm{Ni}-\mathrm{H}_{2}-\mathrm{NH}_{3}$ and $\mathrm{Ni}-\mathrm{H}_{2}$ (fig. S10). 

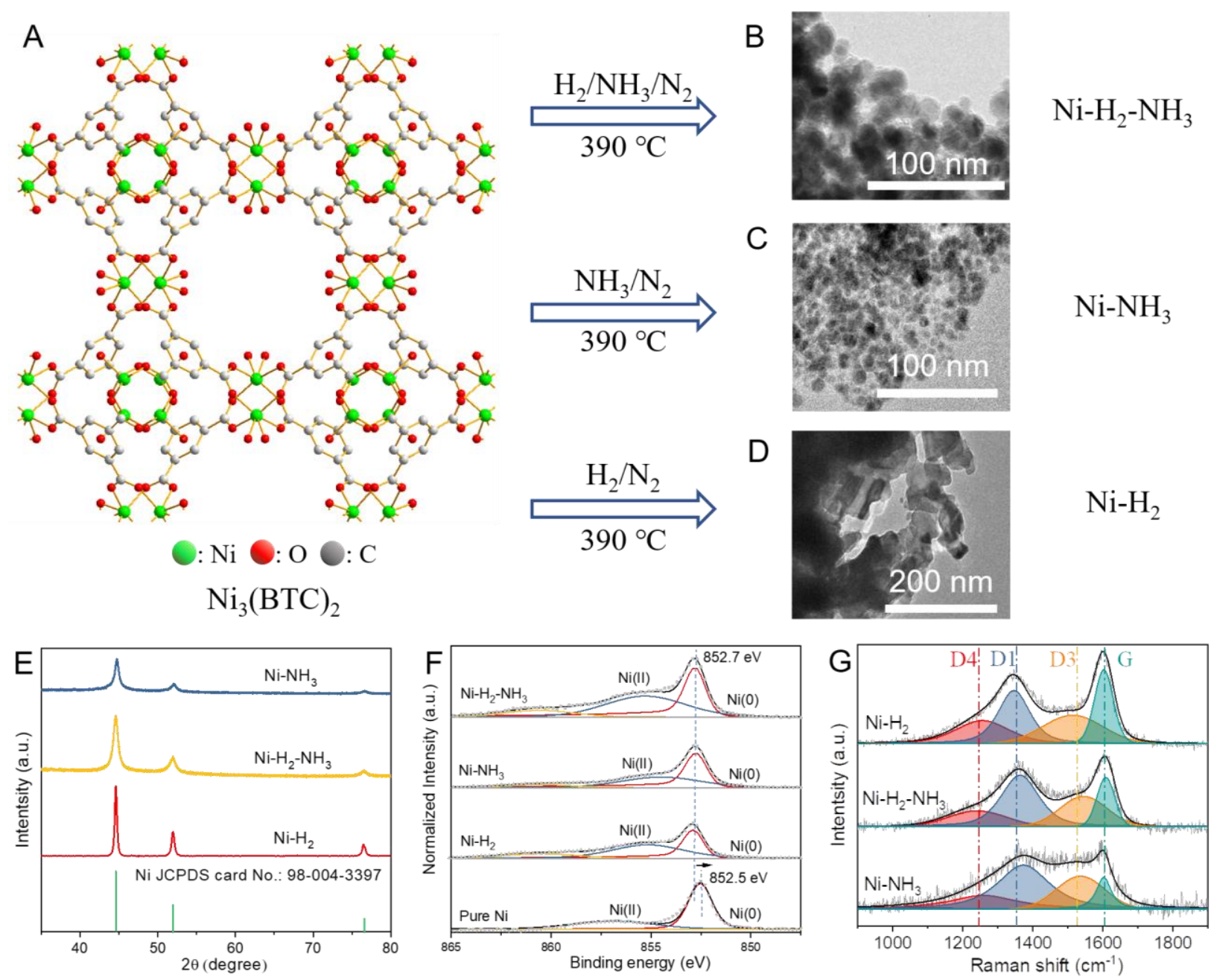

Fig. 1. Synthesis and characterization of Ni catalysts. (A) Schematic illustration of the synthesis of Ni catalysts. TEM image of (B) $\mathrm{Ni}_{2}-\mathrm{H}_{2}-\mathrm{NH}_{3},(\mathbf{C}) \mathrm{Ni}_{-} \mathrm{NH}_{3}$ and (D) $\mathrm{Ni}_{2} \mathrm{H}_{2}$. (E) X-ray diffraction (XRD) patterns of three catalysts. (F) Ni 2p $3 / 2$ XPS spectra and fitting results; (G) Raman spectra and fitting results.

The electrochemical HOR activity of the three nickel catalysts was evaluated in $\mathrm{H}_{2}$-saturated 0.1 $\mathrm{M} \mathrm{KOH}$ and compared to commercial $20 \mathrm{wt}$. \% Pt/C (fig. 2A). The activity of the three Ni catalysts has the following order: $\mathrm{Ni}-\mathrm{H}_{2}-\mathrm{NH}_{3}>\mathrm{Ni}-\mathrm{NH}_{3}>\mathrm{Ni}-\mathrm{H}_{2}$. The linear sweep voltammetry (LSV) curve of $\mathrm{Ni}-\mathrm{H}_{2}-\mathrm{NH}_{3}$ approaches that of $20 \mathrm{wt} \% \mathrm{Pt} / \mathrm{C}$, a benchmark PGM catalyst. Comparison of LSV curves in $\mathrm{N}_{2-}$ and $\mathrm{H}_{2}$-saturated $0.1 \mathrm{M} \mathrm{KOH}$ confirmed that the anodic current observed for $\mathrm{Ni}^{-} \mathrm{H}_{2}-$ $\mathrm{NH}_{3}$ in fig. 2A is originated from hydrogen oxidation (fig. S11).

The kinetic parameters of HOR were extracted using Koutecky-Levich and Butler-Volmer equations (fig. 2B and methods, SM). This analysis yielded two parameters that can be used to compare different catalysts: apparent mass activity at a given overpotential (fig. S12) and 15 electrochemical surface area (ECSA, fig. S13)-normalized exchange current density (j0,ECSA). Ni$\mathrm{H}_{2}-\mathrm{NH}_{3}$ has a mass-averaged current density of $59.2 \mathrm{~mA} / \mathrm{mg}_{\mathrm{Ni}}$ at an overpotential $(\eta)$ of $50 \mathrm{mV}$ 
and a jo,ECSA of $70 \mu \mathrm{A} / \mathrm{cm}^{2}{ }_{\mathrm{Ni}}$. The intrinsic activity, $\mathrm{j}_{0, \mathrm{ECSA}}$, is the highest among Ni-based HOR catalysts and is even higher than a modified Pd catalyst (Table 1).

Table 1. Comparison of state-of-the-art Pt-free HOR catalysts.

\begin{tabular}{|c|c|c|c|}
\hline Catalyst & $\begin{array}{c}\text { Mass activity @ } \boldsymbol{\eta}= \\
50 \mathrm{mV}\left(\mathrm{mA} / \mathrm{mgat}_{\text {cat. }}\right.\end{array}$ & $\begin{array}{c}\text { jo,ECSA } \\
\left(\mu \mathrm{A} / \mathbf{c m}^{2} \text { cat. }\right)\end{array}$ & Reference \\
\hline $\mathrm{Ni}-\mathrm{H}_{2}-\mathrm{NH}_{3}$ & 59.2 & 70 & \\
\hline $\mathrm{Ni}-\mathrm{NH}_{3}$ & 12.7 & 20 & This work \\
\hline $\mathrm{Ni}-\mathrm{H}_{2}$ & 0.8 & 18 & \\
\hline $\mathrm{Ni}_{3} \mathrm{~N} / \mathrm{C}$ & 24.4 & 14 & 18 \\
\hline np- $\mathrm{Ni}_{3} \mathrm{~N}$ & 29.8 & - & 19 \\
\hline $\mathrm{Ni}-\mathrm{H}_{2}-2 \%$ & 50.4 & 28 & 17 \\
\hline $\mathrm{CeO}_{2}(\mathrm{r})-\mathrm{Ni} / \mathrm{C}-1$ & 12.3 & 38 & 14 \\
\hline $\mathrm{Ni} / \mathrm{NiO} / \mathrm{C}-700$ & 5.0 & 26 & 13 \\
\hline $\mathrm{Ni} / \mathrm{N}-\mathrm{CNT}$ & 9.3 & 28 & 12 \\
\hline $\mathrm{Ni} / \mathrm{Ni}_{3} \mathrm{~N} / \mathrm{NF}$ & - & 3 & 20 \\
\hline $\mathrm{Pd} / \mathrm{C}-\mathrm{CeO}_{2}$ & - & 54.5 & 21 \\
\hline
\end{tabular}

An accelerated durability test (ADT) was conducted by performing 1000 cyclic voltammetric (CV) scans from $-0.15 \mathrm{~V}$ to $0.1 \mathrm{~V}$ vs RHE at a scan rate of $100 \mathrm{mV} / \mathrm{s}$. LSV curves show that $\mathrm{Ni}-\mathrm{H}_{2}-\mathrm{NH}_{3}$ had only a small decrease in the HOR activity after this process (fig. 2C). Detailed kinetic analysis indicated that $\mathrm{j}_{0}$, disk decreased to $82 \%$ of its original value. On the contrary, LSV curves indicate significant decrease of $\mathrm{HOR}$ activity for $\mathrm{Ni}^{-\mathrm{NH}_{3}}$ after $1000 \mathrm{CV}$ scans, and $\mathrm{j}_{0}$, disk decreased to $38 \%$ of its original value. CO-resistivity was tested on $\mathrm{Ni}^{-} \mathrm{H}_{2}-\mathrm{NH}_{3}$ and $\mathrm{Pt} / \mathrm{C}(20 \mathrm{wt} \%)$ by measuring LSV in an electrolyte purged with an $\mathrm{H}_{2}$ gas containing 7.5 vol\% $\mathrm{N}_{2}$ or $\mathrm{CO}$. Both materials suffered from $\mathrm{CO}$-poisoning, but $\mathrm{Ni}-\mathrm{H}_{2}-\mathrm{NH}_{3}$ was clearly less affected, suggesting a better $\mathrm{CO}$ resistivity (fig. 2D). In addition, $\mathrm{HOR}$ on $\mathrm{Ni}-\mathrm{H}_{2}-\mathrm{NH}_{3}$ was resistant to high anodic potentials, as it could maintain $3 \mathrm{~mA} / \mathrm{cm}^{2}$ up to $0.23 \mathrm{~V}$ vs RHE (fig. S14).

15 The activity of the three Ni catalysts in the hydrogen evolution reaction (HER), the reverse reaction of HOR, was also investigated in $1 \mathrm{M} \mathrm{KOH}$ (fig. 2E, F). Again, the activity has the order of Ni$\mathrm{H}_{2}-\mathrm{NH}_{3}>\mathrm{Ni}-\mathrm{NH}_{3}>\mathrm{Ni}-\mathrm{H}_{2}$. Ni-H $-\mathrm{NH}_{3}$ again shows very high activity, with an LSV curve approaching that of $\mathrm{Pt} / \mathrm{C}$. The catalyst has a $\eta$ of only $29 \mathrm{mV}$ for $10 \mathrm{~mA} / \mathrm{cm}^{2}$. The activity trend observed by LSV was confirmed by electrochemical impedance spectroscopy (EIS) analysis (fig. $\mathrm{S} 15)$. Comparison using overpotential and Tafel slope indicate that $\mathrm{Ni}-\mathrm{H}_{2}-\mathrm{NH}_{3}$ is among the most 
active noble metal-free HER catalysts in alkaline medium (Table S3). $\mathrm{Ni}_{2}-\mathrm{H}_{2}-\mathrm{NH}_{3}$ had better stability than $\mathrm{Ni}-\mathrm{NH}_{3}$ over an extended period of electrolysis (fig. S16).
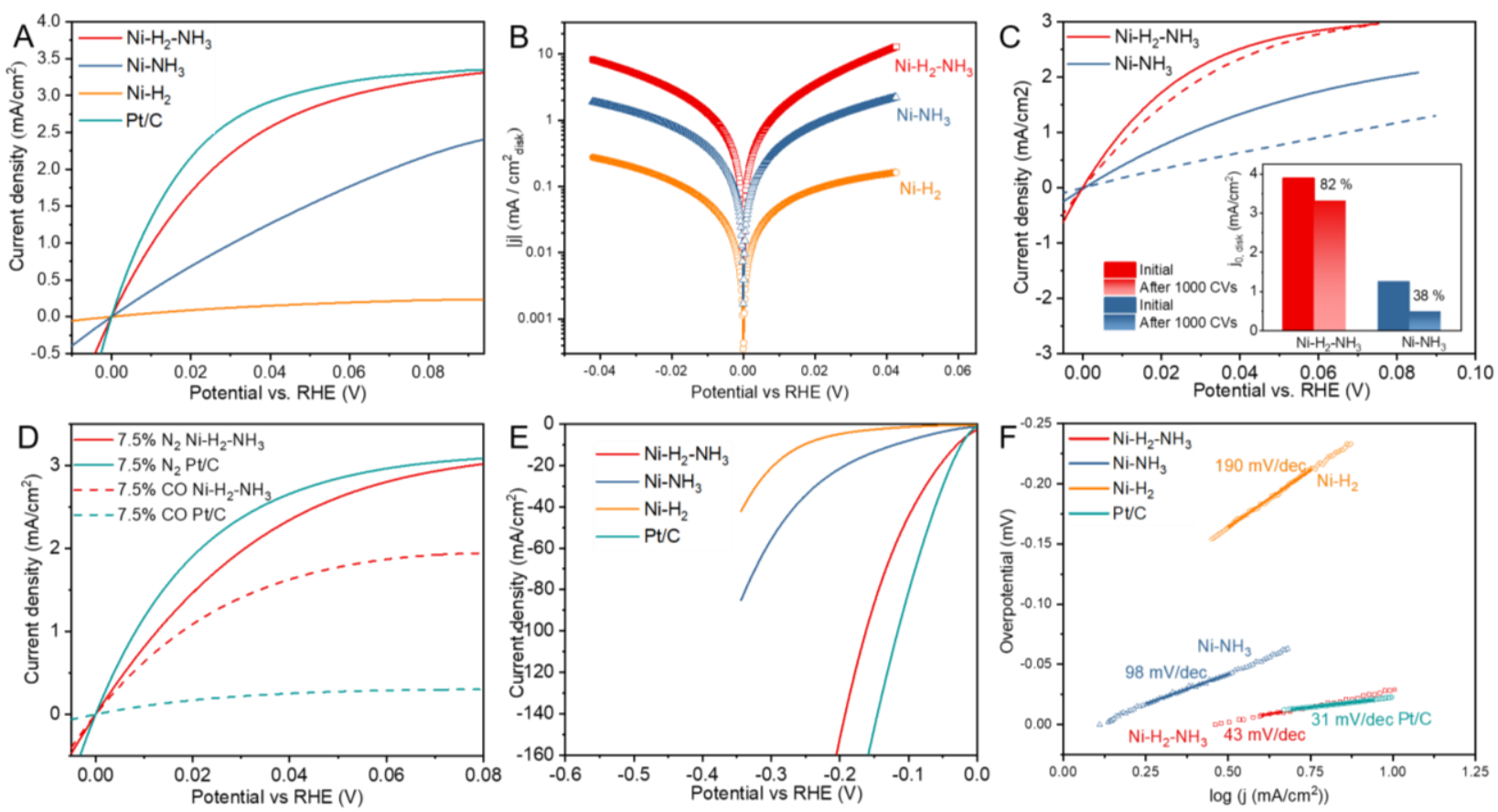

Fig. 2. Electrochemical HOR and HER. (A) HOR polarization curves of $\mathrm{Ni}-\mathrm{H}_{2}-\mathrm{NH}_{3}, \mathrm{Ni}-\mathrm{NH}_{3}$, $\mathrm{Ni}-\mathrm{H}_{2}$ and commercial Pt/C (20 wt\%) with a rotating speed of 2500 r.p.m. (B) Butler-Volmer plots of HOR currents in fig. 2A. (C) Accelerated durability test for $\mathrm{HOR}$ of $\mathrm{Ni}-\mathrm{H}_{2}-\mathrm{NH}_{3}$ and $\mathrm{Ni}-\mathrm{NH}_{3}$. Inset bar plot is a comparison of $\mathrm{j}_{0 \text {, disk }}$ before and after $1000 \mathrm{CVs}$. (D) $\mathrm{CO}$ poisoning experiments for $\mathrm{Ni}-\mathrm{H}_{2}-\mathrm{NH}_{3}$ and $20 \mathrm{wt} \% \mathrm{Pt} / \mathrm{C}$. Five linear sweep scans (LSV) were performed in the COcontaining electrolyte before recording the HOR polarization curve. (E) HER polarization curves of $\mathrm{Ni}-\mathrm{H}_{2}-\mathrm{NH}_{3}, \mathrm{Ni}-\mathrm{NH}_{3}, \mathrm{Ni}-\mathrm{H}_{2}$ and commercial $20 \mathrm{wt} \% \mathrm{Pt} / \mathrm{C}$ in $1 \mathrm{M} \mathrm{KOH}$. (F) Tafel plots of HER currents recorded in fig. $2 \mathrm{E}$.

The mechanism of HOR in alkaline medium is generally proposed to consist of 2 steps: first the dissociation of $\mathrm{H}_{2}$ on the catalyst surface through a Tafel or Heyrovsky step to form adsorbed $\mathrm{H}$ $\left(\mathrm{H}_{\mathrm{ads}}\right)$, then the formed $\mathrm{H}_{\text {ads }}$ is oxidized and combined with $\mathrm{OH}^{-}$to give water through a Volmer step. According to this mechanism, HBE is a descriptor for catalytic activity ${ }^{22,23}$. Recently, a bifunctional mechanism in which adsorbed hydroxyl species $\left(\mathrm{OH}_{\mathrm{ads}}\right)$ facilitates the leaving of $\mathrm{H}_{\mathrm{ads}}$ was also proposed ${ }^{24}$. In this case, $\mathrm{OH}$ binding energy (OHBE) is an additional descriptor for catalytic activity ${ }^{13,14}$. We probed the $\mathrm{HBE}$ and $\mathrm{OHBE}$ of $\mathrm{Ni}-\mathrm{H}_{2}, \mathrm{Ni}-\mathrm{NH}_{3}, \mathrm{Ni}-\mathrm{H}_{2}-\mathrm{NH}_{3}$ and an unsupported Ni reference. 

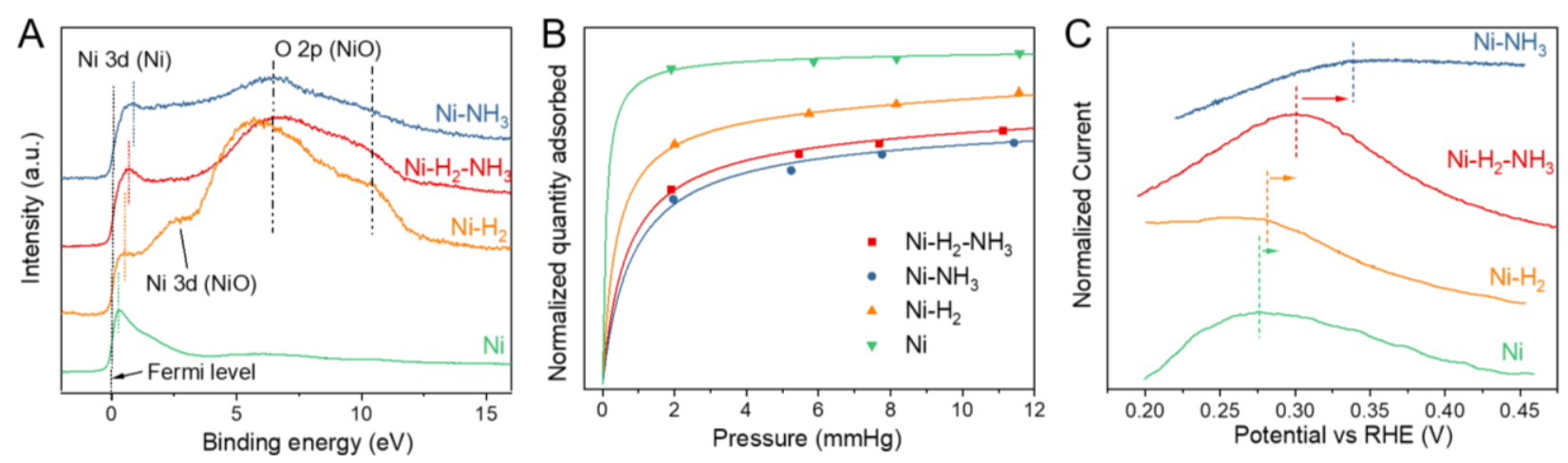

Fig. 3 (A) UPS spectra of $\mathrm{Ni}-\mathrm{H}_{2}-\mathrm{NH}_{3}, \mathrm{Ni}-\mathrm{NH}_{3}, \mathrm{Ni}-\mathrm{H}_{2}$ and a $\mathrm{Ni}$ reference. (B) $\mathrm{H}_{2}$ Chemisorption measurement for $\mathrm{Ni}-\mathrm{H}_{2}-\mathrm{NH}_{3}, \mathrm{Ni}-\mathrm{NH}_{3} \mathrm{Ni}-\mathrm{H}_{2}$ and $\mathrm{Ni}$. The data was scaled to the same quantity adsorbed at saturation for comparison. The dots are measured data, solid lines are fitting results based on the dual-Langmuir model. (C) Anodic scan showing the oxidative adsorption of $\mathrm{OH}^{-}$in $\mathrm{N}_{2}$-saturated $\mathrm{KOH}$ solution for $\mathrm{Ni}-\mathrm{H}_{2}-\mathrm{NH}_{3}, \mathrm{Ni}-\mathrm{NH}_{3} \mathrm{Ni}-\mathrm{H}_{2}$ and $\mathrm{Ni}$.

XPS data already indicated an interfacial charge transfer from $\mathrm{Ni}$ to the carbon support for $\mathrm{Ni}_{-} \mathrm{H}_{2}-$ $\mathrm{NH}_{3}, \mathrm{Ni}-\mathrm{NH}_{3}, \mathrm{Ni}-\mathrm{H}_{2}$. The transfer originates from the differences of work functions of $\mathrm{Ni}$ and carbon, and results in the hybridization of Ni's $3 d$ states with the $\pi$ states of carbon ${ }^{25}$. This interaction alters the electronic structure of $\mathrm{Ni}$ and shifts its $d$ band further away from Fermi level compared to pure $\mathrm{Ni}^{26}$. We further examined the valence state structure of $\mathrm{Ni}$ using ultraviolet photoelectron spectroscopy (UPS). All four Ni samples have electronic bands crossing the Fermi level (fig. 3A), indicative of their metallic nature ${ }^{27,28}$. The peaks next to the Fermi level correspond to metallic Ni 3d states. Their positions increase in binding energy (away from the Fermi level) in the following order: $\mathrm{Ni}<\mathrm{Ni}-\mathrm{H}_{2}<\mathrm{Ni}-\mathrm{H}_{2}-\mathrm{NH}_{3}<\mathrm{Ni}-\mathrm{NH}_{3}$ (fig. S17). According to the $d$ band theory, a downshifted $d$ band leads to weakened adsorption strength ${ }^{29}$. Thus, the HBE and OHBE should follow the following order: $\mathrm{Ni}>\mathrm{Ni}-\mathrm{H}_{2}>\mathrm{Ni}-\mathrm{H}_{2}-\mathrm{NH}_{3}>\mathrm{Ni}-\mathrm{NH}_{3}$.

We probed HBE through $\mathrm{H}_{2}$ chemisorption. The adsorption behavior at the low-pressure region is dominated by chemisorption, and the surface with a stronger hydrogen affinity would reach saturation at a lower pressure. Our data showed the hydrogen binding strength had the order of $\mathrm{Ni}>$ $\mathrm{Ni}-\mathrm{H}_{2}>\mathrm{Ni}-\mathrm{H}_{2}-\mathrm{NH}_{3}>\mathrm{Ni}-\mathrm{NH}_{3}$ (fig. 3B). The order was confirmed by a dual-Langmuir fitting (Supplementary materials, chemisorption) and a differential isotherm (fig. S18). This result agrees with the prediction of the d-band theory.

We determined OHBE by cyclic voltammetry (CV) (fig. 3C). The anodic peaks located between $0.2 \mathrm{~V}$ to $0.4 \mathrm{~V}$ vs RHE are generally assigned to the oxidative adsorption of $\mathrm{OH}$ species, and a higher potential indicates a weaker $\mathrm{OHBE}{ }^{18,30}$. The $\mathrm{OHBE}$ has the following order: $\mathrm{Ni}>\mathrm{Ni}-\mathrm{H}_{2}>$ $\mathrm{Ni}-\mathrm{H}_{2}-\mathrm{NH}_{3}>\mathrm{Ni}-\mathrm{NH}_{3}$. This order is again consistent with the prediction of the d-band theory. While the role of $\mathrm{OH}_{\text {ads }}$ in HOR was uncertain due to the lack of direct observation ${ }^{31,32}$, its presence in the present case was supported by the in-situ observation of a peak located at $\sim 727$ $\mathrm{cm}^{-1}$ in shell-isolated nanoparticles-enhanced Raman (SHINER) spectra of $\mathrm{Ni}_{-}-\mathrm{H}_{2}-\mathrm{NH}_{3}$ at 
potentials relevant to HOR and HER (fig. S19) ${ }^{33}$. Deuterium isotopic substitution experiment confirmed the peak assignment (fig. S19).

The activity trend of the Ni catalysts can be explained by considering their HBEs and OHBEs, which change in a synchronized manner. It is known that pure Ni's HBE is too strong, leading to modest HOR/HER activity ${ }^{19}$. Decreasing HBE increases the activity until an optimal value is reached, which explains the activity trend of $\mathrm{Ni}<\mathrm{Ni}-\mathrm{H}_{2}<\mathrm{Ni}-\mathrm{H}_{2}-\mathrm{NH}_{3}$. Further decreasing HBE will compromise the activity, as demonstrated by the activity drop of $\mathrm{Ni}-\mathrm{NH}_{3}$ compared to $\mathrm{Ni}-\mathrm{H}_{2}-$ $\mathrm{NH}_{3}$. The superior activity of $\mathrm{Ni}-\mathrm{H}_{2}-\mathrm{NH}_{3}$ is, thus, due its optimized HBE. While in some studies the OHBE is proposed to correlate with the activation barrier of Volmer step ${ }^{34}$, and a decreasing OHBE is expected to decrease the HOR activity ${ }^{24}$, our thermodynamic characterizations and analysis indicate that in the present case the influence of HBE dominates. An understanding of the high activity of $\mathrm{Ni}-\mathrm{H}_{2}-\mathrm{NH}_{3}$ in terms of factors beyond thermodynamics, for example, transition state barriers, interfacial electrical field, solvent dynamics, ${ }^{35}$ required further studies.

The Ni catalysts were synthesized by pyrolysis of a same precursor in different gas atmospheres. We probed how the gases influenced the properties and activity of catalysts (Table S4). The main function of $\mathrm{NH}_{3}$ seemed to be the production of N-doped carbon, which according to our UPS data, downshifts Ni's d band, leading to weakened binding energies of adsorbates. A similar effect was previously observed ${ }^{12,37,38}$, which was suggested to originate from the Ni-support interaction and scale with the interfacial contact surface area ${ }^{12,36}$. The Ni nanoparticles in $\mathrm{Ni}-\mathrm{H}_{2}-\mathrm{NH}_{3}$ has are partially embedded in the carbon support, which results in a high interfacial area. The larger interfacial contact leads to a more effective tuning of Ni's electronic property. The extent of dband shift correlates with the $\mathrm{N}$ content (Table $\mathrm{S} 1$ ). Adding $\mathrm{H}_{2}$ prevents the overdoping of nitrogen, leading to a modest $\mathrm{N}$ content, and hence an optimal shift in the d-band. $\mathrm{NH}_{3}$ has two additional counter-balancing roles: (a) it prevents the sintering of particles so that $\mathrm{Ni}-\mathrm{H}_{2}-\mathrm{NH}_{3}$ and $\mathrm{Ni}-\mathrm{NH}_{3}$ are made of much smaller and more evenly distributed particles than $\mathrm{Ni}^{-\mathrm{H}_{2}}$ (fig. 1B-D). (b) it leads to poorly graphitized carbon support, as seen in Raman spectra (Table S2) and HRTEM images (fig. S9). The poor graphitization leads to a low conductivity (fig. S10) and stability (fig. 2C, S16). Adding $\mathrm{H}_{2}$ into $\mathrm{NH}_{3}$ resulted into both good graphitization and small particle size, combing the benefits of both $\mathrm{NH}_{3}$ and $\mathrm{H}_{2}$ while avoiding their pitfalls.

We further incorporated $\mathrm{Ni}-\mathrm{H}_{2}-\mathrm{NH}_{3}$ into membrane electrode assembly (MEA) with a state-ofthe-art poly(aryl piperidinium)-based polymer as membrane and ionomer for HEMFC performance test ${ }^{6}$. For PGM-free MEA, we employed CoMn spinel as ORR catalyst (fig. S20-21) 3,39. The as-prepared $\mathrm{MnCo}_{2} \mathrm{O}_{4} / \mathrm{C}$ catalyst had good ORR activity, showed a half-wave potential only $13 \mathrm{mV}$ lower than a commercial Pt/C catalyst in a RDE configuration (fig. S22). With $\mathrm{Ni}-\mathrm{H}_{2}-$ $\mathrm{NH}_{3}$ as anode, $\mathrm{MnCo}_{2} \mathrm{O}_{4} / \mathrm{C}$ as cathode and $\mathrm{O}_{2}$ as cathodic gas feed, the PGM-free HEMFC delivered a current density of $500 \mathrm{~mA} / \mathrm{cm}^{2}$ at $0.65 \mathrm{~V}$ and reached a high peak power density (PPD) of $450 \mathrm{~mW} / \mathrm{cm}^{2}$ (fig. 4A), 6 times higher than the previous record (fig. 4B) ${ }^{11}$. Replacing $\mathrm{O}_{2}$ to air as cathodic gas feed gave a high PPD of $305 \mathrm{~mW} / \mathrm{cm}^{2}$ and approaches the $600 \mathrm{~mW} / \mathrm{cm}^{2}$ target set 
by US DOE for $2030^{2}$. The promising performance of our PGM-free HEMFC indicates the feasibility of efficient HEMFCs without PGM catalysts.

We also assembled MEAs with PGM ORR catalysts and measured their performance. When using $0.2 \mathrm{mg} / \mathrm{cm}^{2} \mathrm{Pt} / \mathrm{C}$ as cathode and $\mathrm{O}_{2}$ as cathodic gas feed, the fuel cell delivered a PPD of 628 $\mathrm{mW} / \mathrm{cm}^{2}$ (fig. $4 \mathrm{C}$ ) and a current density of $780 \mathrm{~mA} / \mathrm{cm}^{2}$ at $0.65 \mathrm{~V}$ (estimated operating cell voltage constrained by heat rejection in stack). This performance exceeds all the previously reported fuel cells with $\mathrm{Ni}$-anode, and it is even comparable to some recently reported fuel cells with non-Pt PGM anode (fig. 4D). Moreover, durability test of this HEMFC at $95{ }^{\circ} \mathrm{C}$ with constant voltage of $0.7 \mathrm{~V}$ showed only $7 \%$ degradation of current density after $40 \mathrm{~h}$ (fig. S23), demonstrating the ability of our catalyst to work steadily under high temperature and large current. Pt immigration to Ni-based anode in fuel cell test was excluded from the XPS spectra of anode surface after durability test. (fig S24) Meanwhile, the metallic particles in $\mathrm{Ni}_{2}-\mathrm{H}_{2}-\mathrm{NH}_{3}$ were stable after durability test (see TEM images in fig S25). $\mathrm{H}_{2}$ /air feeds were employed to match the test conditions U.S. DOE 2021 target for HEMFCs, which demands a power density of $100 \mathrm{~mW} / \mathrm{cm}^{2}$ at $0.8 \mathrm{~V}$ with $\mathrm{H}_{2}$-air gas feeds ( $\leq 250 \mathrm{kPa}$ pressure) for HEMFC with PGM loading no more than $0.2 \mathrm{mg} / \mathrm{cm}^{2}$. Our MEA with a power density of $120 \mathrm{~mW} / \mathrm{cm}^{2}$ (fig. $4 \mathrm{E}$ ) measured under this specific condition surpassed the targeted value. Increasing the back pressure to $250 \mathrm{kPag}$ resulted in a power density of $160 \mathrm{~mW} \mathrm{~cm}{ }^{-2}$ at $0.8 \mathrm{~V}$, a current density of $590 \mathrm{~mA} / \mathrm{cm}^{2}$ at $0.65 \mathrm{~V}$ and a PPD of $500 \mathrm{~mW} / \mathrm{cm}^{2}$. This performance is comparable to MEAs using advanced Pd catalysts (fig. 4F). We noticed that other MEAs using PGM-free ORR catalysts and PGM-based HOR catalysts could perform better under similar conditions ${ }^{3,4,39}$. However, it is known that PGM-free ORR catalysts have comparable performances to PGM catalysts, while the PGM-free HOR catalysts are more than one order of magnitude less active than their PGM counterparts. Therefore, a better performance of PGM anode|PGM-free cathode MEA configuration than the PGM-free anode|PGM cathode configuration is expected. Nevertheless, we compared the total PGM utilization by calculating the peak power density per massPGM (fig. 4G, 4H). The PGM utilization of our Ni- $\mathrm{H}_{2}-\mathrm{NH}_{3}$ anode|Pt cathode MEA not only leads in the category of PGM-free anode|PGM cathode MEAs, but also approaches state-of-the-art PGM anode|PGM-free cathode MEAs. Overall the superior activity and robustness of the new $\mathrm{Ni}$ catalyst under device-relevant conditions demonstrate the potential of Earth-abundant HOR catalysts for the development of efficient PGMfree HEMFCs. 

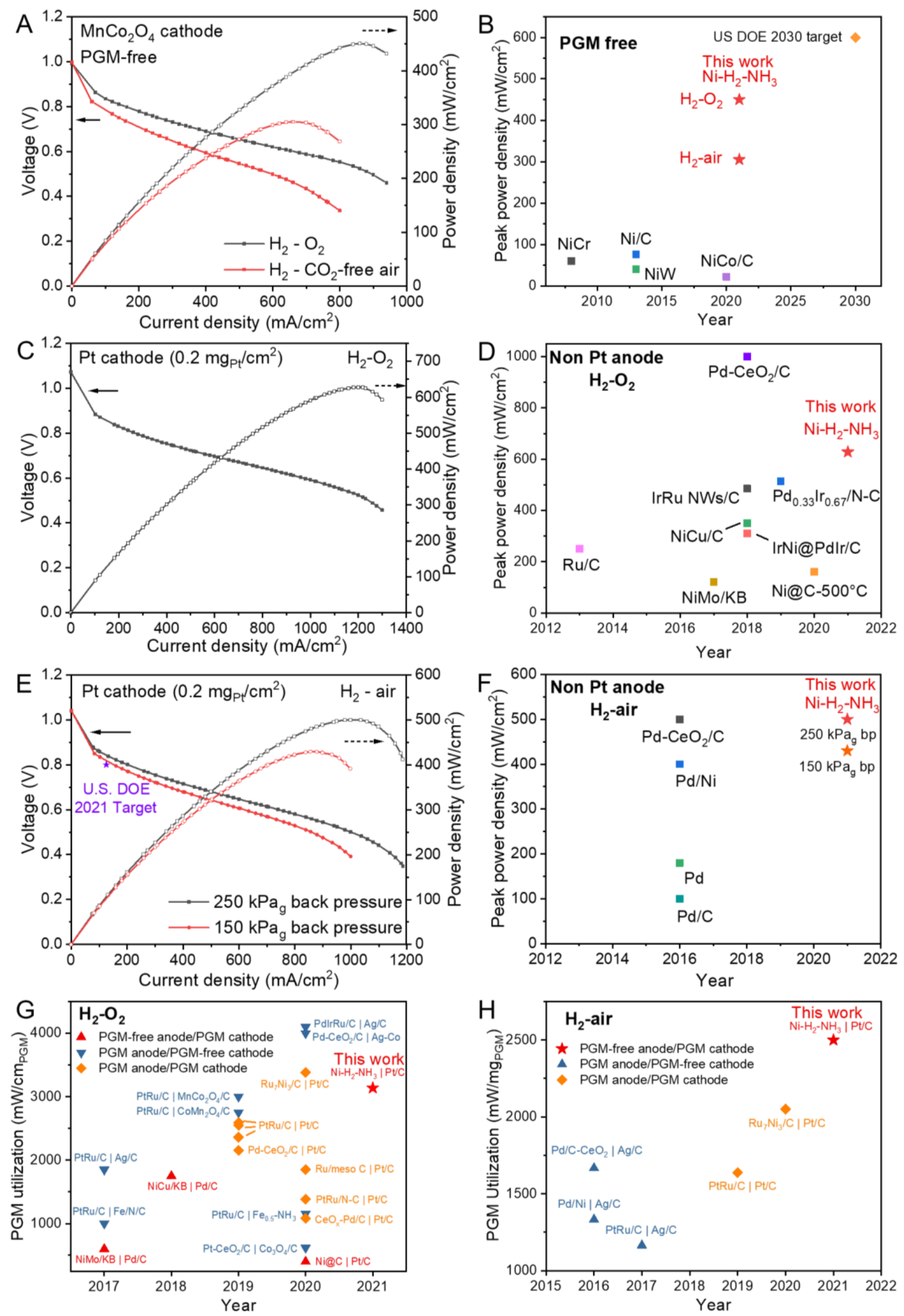
Fig. 4 Hydrogen fuel cell performance using $\mathrm{Ni}-\mathrm{H}_{2}-\mathrm{NH}_{3}$ as anode. (A) PGM-free $\mathrm{H}_{2}-\mathrm{O}_{2} \mathrm{HEMFC}$ performance using Co-Mn spinel as cathode catalyst. Test condition: cell temperature at $95.0{ }^{\circ} \mathrm{C}$, cathode humidifier at $96.0^{\circ} \mathrm{C}$, anode humidifier at $88.0^{\circ} \mathrm{C}, \mathrm{H}_{2}$ flow rate $0.2 \mathrm{~L} / \mathrm{min}$ and $\mathrm{O}_{2} /$ air flow rate $0.2 / 1 \mathrm{~L} \mathrm{~min}^{-1}$ with $250 \mathrm{kPag}$ back pressure on both sides. (B) Comparison of our PGM-free MEA results with previously reported results (all tested with $\mathrm{H}_{2}-\mathrm{O}_{2}$ gas feed). Details are listed in Table S4. (C) Polarization and power density curves using $\mathrm{Pt} / \mathrm{C}$ as cathode material. Test condition was the same as in fig. 4A. (D) Comparison of our MEA results with other non-Pt anode MEAs performance with $\mathrm{H}_{2}-\mathrm{O}_{2}$ gas feed. These MEAs used a Pt, $\mathrm{Pd}$ or Ag cathode. Details are listed in Table S5. (E) Hydrogen-air fuel cell performance using $\mathrm{Ni}-\mathrm{H}_{2}-\mathrm{NH}_{3}$ as anode and $\mathrm{Pt} / \mathrm{C}(0.2$ $\mathrm{mg}_{\mathrm{Pt}} / \mathrm{cm}^{2}$ ) as cathode. Test condition cell temperature at $95{ }^{\circ} \mathrm{C}$, cathode humidifier at $96.0{ }^{\circ} \mathrm{C}$, anode humidifier at $88.0^{\circ} \mathrm{C}, \mathrm{H}_{2}$ flow rate $0.2 \mathrm{~L} / \mathrm{min}$ and air flow rate $1 \mathrm{~L} / \mathrm{min}$ with specific back pressure on both sides. The purple star marks the DOE 2021 target for HEMFCs ${ }^{2}$. (F). Comparison of our MEA results with other non-Pt anode MEAs performance with $\mathrm{H}_{2}$-air gas feed. Comparisons of PGM utilization of our MEA with other state-of-the-art MEAs with (G) $\mathrm{H}_{2}-\mathrm{O}_{2}$ and (H) $\mathrm{H}_{2}$-air gas feed. In each case the electrode materials were given in the form of 'anode catalyst | cathode catalyst'. Details are listed in Table S6.

\section{Materials and Methods}

\section{Materials}

Nickel nitrate hexahydrate $\left(\mathrm{Ni}\left(\mathrm{NO}_{3}\right)_{2} \cdot 6 \mathrm{H}_{2} \mathrm{O}, 99.9 \% \mathrm{Ni}, \mathrm{ABCR}\right), 1,3,5$-Benzenetricarboxylic Acid (BTC, >98\%, TCI), Cobalt(II) acetate tetrahydrate $\left(\mathrm{Co}(\mathrm{OAc})_{2} \cdot 4 \mathrm{H}_{2} \mathrm{O},>98 \%\right.$, Sigma-Aldrich), Manganese(II) acetate tetrahydrate $\left(\mathrm{Mn}(\mathrm{OAc})_{2} \cdot 4 \mathrm{H}_{2} \mathrm{O},>=99 \%\right.$, Sigma-Aldrich), Hydrogen $\left(\mathrm{H}_{2}\right.$, Carbagas, 99.999\%) for HOR test, ammonia $\left(\mathrm{NH}_{3}, \mathrm{~N} 38\right.$, Air Liquide) and Ethanol (EtOH, Tech grade, with $1 \%$ Toluene, Thommen Furler AG) were used as received without further purification. N,NDimethylformamide (DMF, HPLC grade, Roth) was purified through a solvent purification system. Hydrogen $\left(\mathrm{H}_{2}\right)$ for pyrolysis was generated by a $\mathrm{H}_{2}$ generator, with a concentrated sulfuric acid trap to adsorb possible $\mathrm{H}_{2} \mathrm{O}$ vapor.

\section{Methods}

\section{Synthesis of nanocrystalline $\mathrm{Ni}_{3}(\mathrm{BTC})_{2}$}

The $\mathrm{Ni}_{3}(\mathrm{BTC})_{2}$ was prepared by modifying a reported method ${ }^{40} . \mathrm{H}_{3} \mathrm{BTC}(0.41 \mathrm{~g}, 1.95 \mathrm{mmol})$ and $\mathrm{Ni}\left(\mathrm{NO}_{3}\right)_{2} \cdot 6 \mathrm{H}_{2} \mathrm{O}$ were placed in different positions in a $45 \mathrm{~mL}$ Teflon-lined autoclave. $30 \mathrm{~mL}$ anhydrous DMF was slowly added without any agitation. The autoclave was then sealed and kept at $120{ }^{\circ} \mathrm{C}$ for 12 h. The autoclave was opened after cooling down to room temperature. The product mixture contained big bright-green crystals and light-green powders. XRD showed that only the light-green powders were the desired $\mathrm{Ni}_{3}$ (BTC) $)_{2}$ (Fig. S1). Since the powder was easily dispersed while the big crystals were not, they can be separated by first sonicating the solution and then discarding the supernatant. The final product was obtained by centrifuging the dispersion and further washing three times with ethanol, then drying at $70{ }^{\circ} \mathrm{C}$ overnight. The product is very sensitive to water vapor, so it should be stored in a dry atmosphere. 
The catalysts were prepared by temperature-programmed pyrolysis of $\mathrm{Ni}_{3}(\mathrm{BTC})_{2}$ under a gas flow. Typically, for the synthesis of $\mathrm{Ni}-\mathrm{H}_{2}-\mathrm{NH}_{3}, 20 \mathrm{mg} \mathrm{Ni}_{3}$ (BTC) $)_{2}$ was put into a crucible and placed in the center of a pipe furnace. The furnace was first purged with $\mathrm{N}_{2}$ for $10 \mathrm{~min}$ and then heated to $170{ }^{\circ} \mathrm{C}$ with a ramp rate of $10{ }^{\circ} \mathrm{C} / \mathrm{min}$ under a mixed gas flow of $21.6 \mathrm{~mL} / \mathrm{min}_{2}$ and $289.0 \mathrm{~mL} / \mathrm{min} \mathrm{N}_{2}$. When the temperature reaches $175^{\circ} \mathrm{C}, 157.0 \mathrm{~mL} / \mathrm{min} \mathrm{NH}_{3}$ is introduced into the reaction. The oven is continuously heated to 390 ${ }^{\circ} \mathrm{C}$ and then kept for $1 \mathrm{~h}$, and finally cooled down to room temperature under an $\mathrm{N}_{2}$ atmosphere. Before taking the product out of the furnace, a small amount of ethanol was injected into the crucible through a long syringe needle to prevent the pyrophoric re-oxidation of the catalyst (exception: in order to minimize the surface oxidation and passivation, samples for $\mathrm{H}_{2}$ adsorption measurements were directly transferred to a glove box without being taken out from the tube furnace). After drying under an $\mathrm{N}_{2}$ flow, the samples are collected and stored in inert atmosphere.

For $\mathrm{Ni}-\mathrm{H}_{2}$ and $\mathrm{Ni}-\mathrm{NH}_{3}$, the synthetic procedure was similar as above: $\mathrm{Ni}-\mathrm{H}_{2}$ was prepared without adding $\mathrm{NH}_{3}$ and $\mathrm{Ni}-\mathrm{NH}_{3}$ was prepared without adding $\mathrm{H}_{2}$. The gas flow was monitored by a Supelco Rotameter with a needle valve. The float material for $\mathrm{H}_{2}, \mathrm{NH}_{3}$ and $\mathrm{N}_{2}$ were glass, stainless steel and carboloy.

\section{Preparation of $\mathrm{C}-\mathrm{H}_{2}-\mathrm{NH}_{3}, \mathrm{C}-\mathrm{H}_{2}$ and $\mathrm{C}-\mathrm{NH}_{3}$}

The $\mathrm{Ni}-\mathrm{H}_{2}-\mathrm{NH}_{3}, \mathrm{Ni}-\mathrm{H}_{2}$ and $\mathrm{Ni}-\mathrm{NH}_{3}$ samples were dispersed in $2 \mathrm{M} \mathrm{HCl}$ and stirred overnight to remove the $\mathrm{Ni}$ nanoparticles. Then the samples were washed with $\mathrm{H}_{2} \mathrm{O}$ and ethanol for 3 times. The samples then were dispersed in ethanol for further characterization. They were labelled as $\mathrm{C}-\mathrm{H}_{2}-\mathrm{NH}_{3}, \mathrm{C}-\mathrm{H}_{2}$ and $\mathrm{C}-\mathrm{NH}_{3}$, correspondingly.

\section{Preparation of Co-Mn spinel}

Co-Mn spinel was synthesized by modifying a reported method ${ }^{39}$. Generally, $\mathrm{Co}(\mathrm{OAc})_{2} \cdot 4 \mathrm{H}_{2} \mathrm{O}(135.5 \mathrm{mg})$ was firstly dissolved in $4 \mathrm{~mL} \mathrm{H}_{2} \mathrm{O}$, then $64 \mathrm{mg}$ oxidized Vulkan XC-72R carbon dispersed in $30 \mathrm{~mL}$ ethanol was added into it. The mixture was sonicated for $10 \mathrm{~min}$. Then $0.44 \mathrm{~mL}$ ammonia and $24 \mathrm{~mL}$ ethanol were added dropwise. After the suspension was sonicated for $10 \mathrm{~min}$, the solution of $\mathrm{Mn}(\mathrm{OAc})_{2} \cdot 4 \mathrm{H}_{2} \mathrm{O}(66.6 \mathrm{mg})$ dissolved in $1.5 \mathrm{~mL}$ water was added. The final suspension was heated at $60{ }^{\circ} \mathrm{C}$ for $13 \mathrm{~h}$ under reflux then transferred to Teflon autoclave for hydrothermal reaction at $150{ }^{\circ} \mathrm{C}$ for $3 \mathrm{~h}$. The Co-Mn spinel/C product was collected by centrifugation and washed with ethanol, then dried under vacuum.

\section{Materials characterization}

Transmission electron microscopy (TEM) was carried out on a FEI Tecnai Osiris electron microscope equipped with a high-brightness field emission gun (XFEG) and an energy dispersive X-ray spectroscopy (EDX) analyzer. The TEM samples were prepared by drop-drying the catalysts on ultrathin carbon coatedcopper grids.

Powder X-ray diffraction (PXRD) patterns were recorded on an PANalytical Aeris diffractometer with monochromatic $\mathrm{Cu}$ K- $\alpha$ radiation $(\lambda=1.540598 \AA)$. The PXRD samples were prepared by drop-drying the catalysts on amorphous silicon substrates.

X-ray photoelectron spectroscopy (XPS) measurements were carried out using a PHI VersaProbe II scanning XPS microprobe. 
UPS He II spectra were acquired at an excitation energy of $40.82 \mathrm{eV}$ using a hemispherical electron analyzer SPECS Leybold EA $11 \mathrm{MCD}$ in ultrahigh vacuum conditions with a base pressure of $5 \times 10^{-10}$ mbar. The binding energy scale was calibrated by measuring the Fermi level of an Au sample. The samples were subjected to soft Ar ion sputtering of $1 \mathrm{kV}$ for a duration of $30 \mathrm{~s}$ to remove surface oxide and other contamination.

Thermogravimetric analysis (TGA) measurements were carried out on a TGA 4000 from Perkin Elmer. The starting temperature was $30{ }^{\circ} \mathrm{C}$, with $5{ }^{\circ} \mathrm{C} / \mathrm{min}$ ramp rate to $900{ }^{\circ} \mathrm{C}$ and stayed at $900{ }^{\circ} \mathrm{C}$ for $5 \mathrm{~min}$ under a $20 \mathrm{~mL} / \mathrm{min}$ air flow. After the analysis, the residue was collected for PXRD measurement to determine the phase.

Raman spectra were recorded on a RENISHAW inVia confocal Raman microscope. The scattered light was collected by a charge coupled device (CCD) detector. Every time prior to use, the Raman shift was calibrated by measuring an inner standard Si. For in situ measurement, an reported technique called shellisolated nanoparticle-enhanced Raman spectroscopy (SHINERS) was applied ${ }^{33}$. An extra electrochemical cell was mounted on the sample stage, and $0.01 \mathrm{M} \mathrm{KOH}$ or KOD was used as the electrolyte with $\mathrm{H}_{2}$ purging. Before recording the signal, the sample was reduced at $-0.3 \mathrm{~V}$ vs RHE for $3 \mathrm{~min}$ to remove the surface oxide layer.

The conductivity was tested in ambient air by four-point probe method using a Keithley 2400 source measure unit with 4-wire setup. The Ni/C circular pellets with a diameter of $13 \mathrm{~mm}$ were prepared under a pressure of 8 ton-force to perform the conductivity measurement.

Volumetric measurements of $\mathrm{H}_{2}$ adsorption isotherms were measured at $35^{\circ} \mathrm{C}$ between 2 and 600 mbar on a Micromeritics 3 Flex instrument. The sample $(300 \mathrm{mg}$ ) was loaded into a glass cell inside a nitrogen filled glovebox, transferred to the instrument and dried in-situ under vacuum $(<10-3 \mathrm{mbar})$ at $120{ }^{\circ} \mathrm{C}$ for 1 hour. After cooling down to $35^{\circ} \mathrm{C}$ under vacuum, a leak test was performed prior to analysis. Quantities adsorbed $\left(\mathrm{Q}_{\mathrm{i}}\right)$ and adsorption constants $\left(\mathrm{k}_{\mathrm{i}}\right)$ were extracted by fitting a dual Langmuir adsorption model (Matlab) accounting for weak $(\mathrm{k}<0.1)$ and strong adsorption $(\mathrm{k}>0.1)$.

\section{Electrochemical measurements}

All electrochemical tests were performed in a standard three-electrode system controlled by either a CHI $760 \mathrm{E}$ or Gamry electrochemical workstation. All the data were iR-corrected. A KCl-saturated Ag/AgCl electrode was used as the reference electrode (RE), and a clean platinum wire was used as the counter electrode (CE). During HER stability test, an extra frit was used for CE to prevent Pt contamination. The HOR measurements were performed in $\mathrm{H}_{2}$-saturated $0.1 \mathrm{M} \mathrm{KOH}$, and the catalyst ink was casted onto a glassy carbon rotating disk electrode of $5 \mathrm{~mm}$ in diameter to form a thin film layer $\left(0.28 \mathrm{mg} / \mathrm{cm}^{2}\right.$ cat. $)$. The HER measurements were performed in $1 \mathrm{M} \mathrm{KOH}$ using a $3 \mathrm{~mm}$ diameter glassy carbon as the working electrode with a loading of $0.42 \mathrm{mg} / \mathrm{cm}^{2}$ cat. Electrochemical impedance spectroscopy (EIS) measurements were carried out by AC voltage with a $5 \mathrm{mV}$ amplitude in $1 \mathrm{M} \mathrm{KOH}$ solution at $\eta=100 \mathrm{mV}$. The frequency ranges from $0.1 \mathrm{MHz}$ to $0.1 \mathrm{~Hz}$. For HER and HOR measurements, the scan rate was $1 \mathrm{mV} / \mathrm{s}$, while for cyclic voltammetry measurements, the scan rate was $50 \mathrm{mV} / \mathrm{s}$. Unless specified, all potential used in this paper are referred to RHE potential, which was calibrated by performing LSV scan with Pt/C as working electrode material in $\mathrm{H}_{2}$-saturated electrolyte. 
To calculate the kinetic current density, Koutecky - Levich equation (eq. 1) was used to describe a process controlled by both kinetics and diffusion $\left(\mathrm{j}<0.8 \cdot \mathrm{j}_{\mathrm{d}}\right)$ :

$$
\frac{1}{j}=\frac{1}{j_{k}}+\frac{1}{j_{d}}=\frac{1}{j_{k}}+\frac{1}{B c_{0} \omega^{1 / 2}}
$$

Where $j_{k}$ is the kinetic current and $j_{d}$ is the diffusion limited current which can be further expanded according to Levich equation (eq. 2):

$$
j_{d}=0.62 n F D^{2 / 3} v^{-1 / 6} c_{0} \omega^{1 / 2}=B c_{0} \omega^{1 / 2}
$$

$\mathrm{n}$ is the electron transfer number during the reaction, $\mathrm{F}$ is Faraday constant, D is diffusion coefficient of $\mathrm{H}_{2}$ and $v$ is kinematic viscosity of the $0.1 \mathrm{M} \mathrm{KOH}$. These four factors as well as the constant 0.62 in eq. S2 can be simplified by replacing with Levich constant B. $c_{0}$ is the solubility of $\mathrm{H}_{2}$ in electrolyte. By fitting current at an overpotential of $25 \mathrm{mV}$ with eq. $\mathrm{S} 1$, we obtained the value of $\left(\mathrm{Bc}_{0}\right)^{-1}$ as $4.86 \mathrm{~cm}^{2} \mathrm{~mA}^{-1} \mathrm{~s}^{-1 / 2}$ (fig. S11), close to the theoretical value $4.87 \mathrm{~cm}^{2} \mathrm{~mA}^{-1} \mathrm{~s}^{-1 / 2} 41$. Using this $\mathrm{Bc}_{0}$, we can calculate the $\mathrm{j}_{\mathrm{k}}$ at other potentials within the range where eq. $\mathrm{S} 1$ is applicable.

The exchange current density $\mathrm{j}_{0}$ can be obtained by fitting $\mathrm{j}_{\mathrm{k}}$ and $\eta$ with Butler-Volmer equation:

$$
j_{k}=j_{0}\left(e^{\frac{\alpha F}{R T} \eta}-e^{\frac{(\alpha-1) F}{R T} \eta}\right)
$$

where $\alpha$ is charge transfer coefficient, $\mathrm{F}$ is Faraday's constant $\left(96485 \mathrm{C} \mathrm{mol}^{-1}\right), \mathrm{R}$ is the universal gas constant $\left(8.314 \mathrm{~J} \mathrm{~mol}^{-1} \mathrm{~K}^{-1}\right)$, T is temperature and $\eta$ is overpotential. The obtained Tafel plot was shown in fig. 2B. Extrapolating the curve with fitted $\mathrm{j}_{0}$ and $\alpha$, we can calculate $\mathrm{j}_{\mathrm{k}}$ at potentials where eq. 1 cannot be applied anymore. Here $\mathrm{j}_{\mathrm{k}}$ at $\eta=50 \mathrm{mV}$ for $\mathrm{Ni}-\mathrm{H}_{2}-\mathrm{NH}_{3}$ was calculated using this method.

\section{Membrane electrode assembly measurement}

The electrode ink was prepared by adding catalyst, additional Vulcan XC-72 carbon for anode ink only, and ionomer to isopropanol solvent, followed by sonication for $1 \mathrm{~h}$. The weight ratio of Vulcan XC-72 carbon and $\mathrm{Ni}-\mathrm{H}_{2}-\mathrm{NH}_{3}$ catalyst was $1: 1$, and the weight ratio of PAP-TP-100 (molar ratio between Nmethyl-4-piperidone and terphenyl monomers is 1.0) ionomer and carbon support was 0.33 for both anode and cathode. Then the ink including Ni was sprayed onto Sigracet SGL 25BA carbon paper by airbrush to produce a gas diffusion electrode (GDE) of $5 \mathrm{~cm}^{2}$ for anode, while the ink including spinel catalyst was sprayed onto PAP-TP-85 (molar ratio between N-methyl-4-piperidone and terphenyl monomers is 0.85 ) membrane $(18 \pm 2 \mu \mathrm{m})$ to produce catalyst coated on membrane $(\mathrm{CCM})$ of $5 \mathrm{~cm}^{2}$ for cathode. The final catalyst loading was $6.4 \mathrm{mg}_{\mathrm{Ni}} \mathrm{cm}^{-2}$ for anode and $1.2 \mathrm{mg}_{\mathrm{cat}} \mathrm{cm}^{-2}$ for Co-Mn spinel catalyst. After drying at room temperature, the MEA was immersed into $2 \mathrm{M} \mathrm{KOH}$ aqueous solution for 0.5 hour to remove absorbed $\mathrm{CO}_{2}$ in catalyst layers. Then the residual $\mathrm{KOH}$ solution on MEA would be rinsed before test.

The MEA was assembled with a fluorinated ethylene propylene (FEP) gasket, a piece of carbon paper (Sigracet SGL 29 BC) for gas diffusion layer on cathode side, a graphite bipolar plate with $5 \mathrm{~cm}^{2}$ flow field (ElectroChem) and a gold-coated current collector for each side to complete the full HEMFC. Fuel cell test station (Scribner 850e) with back pressure regulators was used for polarization curve and stability test under $\mathrm{H}_{2} / \mathrm{O}_{2}$ or $\mathrm{H}_{2} / \mathrm{CO}_{2}$-free air condition. 


\section{References:}

1 Setzler, B. P., Zhuang, Z., Wittkopf, J. A. \& Yan, Y. Activity targets for nanostructured platinum-group-metal-free catalysts in hydroxide exchange membrane fuel cells. Nat. Nanotechnol. 11, 1020-1025, doi:10.1038/nnano.2016.265 (2016).

2 Thompson, S. T., Peterson, D., Ho, D. \& Papageorgopoulos, D. Perspective-The Next Decade of AEMFCs: Near-Term Targets to Accelerate Applied R\&D. J. Electrochem. Soc. 167, 084514, doi:10.1149/1945-7111/ab8c88 (2020).

3 Wang, Y. et al. Synergistic Mn-Co catalyst outperforms Pt on high-rate oxygen reduction for alkaline polymer electrolyte fuel cells. Nat. Commun. 10, 1506, doi:10.1038/s41467019-09503-4 (2019).

4 Santori, P. G. et al. High Performance FeNC and Mn-oxide/FeNC Layers for AEMFC Cathodes. J. Electrochem. Soc. 167, 134505, doi:10.1149/1945-7111/abb7e0 (2020).

5 Peng, X. et al. High-Performing PGM-Free AEMFC Cathodes from Carbon-Supported Cobalt Ferrite Nanoparticles. Catalysts 9, 264, doi:10.3390/catal9030264 (2019).

6 Wang, J. et al. Poly(aryl piperidinium) membranes and ionomers for hydroxide exchange membrane fuel cells. Nat. Energy 4, 392-398, doi:10.1038/s41560-019-0372-8 (2019).

7 Firouzjaie, H. A. \& Mustain, W. E. Catalytic Advantages, Challenges, and Priorities in Alkaline Membrane Fuel Cells. ACS Catal. 10, 225-234, doi:10.1021/acscatal.9b03892 (2020).

8 Ramaswamy, N. \& Mukerjee, S. Alkaline Anion-Exchange Membrane Fuel Cells: Challenges in Electrocatalysis and Interfacial Charge Transfer. Chem. Rev. 119, 1194511979, doi:10.1021/acs.chemrev.9b00157 (2019).

9 Dekel, D. R. Review of cell performance in anion exchange membrane fuel cells. $J$. Power Sources 375, 158-169, doi:10.1016/j.jpowsour.2017.07.117 (2018).

10 Pan, Z. F., An, L., Zhao, T. S. \& Tang, Z. K. Advances and challenges in alkaline anion exchange membrane fuel cells. Prog. Energy Combust. Sci. 66, 141-175, doi:10.1016/j.pecs.2018.01.001 (2018).

$11 \mathrm{Gu}, \mathrm{S}$. et al. An efficient Ag-ionomer interface for hydroxide exchange membrane fuel cells. Chem. Commun. 49, 131-133, doi:10.1039/c2cc34862d (2013).

12 Zhuang, Z. et al. Nickel supported on nitrogen-doped carbon nanotubes as hydrogen oxidation reaction catalyst in alkaline electrolyte. Nat. Commun. 7, 10141, doi:10.1038/ncomms10141 (2016).

13 Yang, Y. et al. Enhanced Electrocatalytic Hydrogen Oxidation on Ni/NiO/C Derived from a Nickel-Based Metal-Organic Framework. Angew. Chem. Int. Ed. 58, 1064410649, doi:10.1002/anie.201905430 (2019).

14 Yang, F. et al. Boosting Hydrogen Oxidation Activity of Ni in Alkaline Media through Oxygen-Vacancy-Rich CeO2 /Ni Heterostructures. Angew. Chem. Int. Ed. 58, 1417914183, doi:10.1002/anie.201908194 (2019). 
15 Davydova, E., Zaffran, J., Dhaka, K., Toroker, M. \& Dekel, D. Hydrogen Oxidation on Ni-Based Electrocatalysts: The Effect of Metal Doping. Catalysts 8, 454, doi:10.3390/catal8100454 (2018).

16 Oshchepkov, A. G. et al. Nanostructured nickel nanoparticles supported on vulcan carbon as a highly active catalyst for the hydrogen oxidation reaction in alkaline media. J. Power Sources 402, 447-452, doi:10.1016/j.jpowsour.2018.09.051 (2018).

$17 \mathrm{Ni}$, W. et al. Efficient Hydrogen Oxidation Catalyzed by Strain-Engineered Nickel Nanoparticles. Angew Chem. Int. Ed. 59, 10797-10801, doi:10.1002/anie.201916314 (2020).

$18 \mathrm{Ni}$, W. et al. $\mathrm{Ni3} \mathrm{N}$ as an Active Hydrogen Oxidation Reaction Catalyst in Alkaline Medium. Angew. Chem. Int. Ed. 58, 7445-7449, doi:10.1002/anie.201902751 (2019).

19 Wang, T. et al. Weakening hydrogen adsorption on nickel via interstitial nitrogen doping promotes bifunctional hydrogen electrocatalysis in alkaline solution. Energy Environ. Sci. 12, 3522-3529, doi:10.1039/c9ee01743g (2019).

20 Song, F. et al. Interfacing nickel nitride and nickel boosts both electrocatalytic hydrogen evolution and oxidation reactions. Nat. Commun. 9, 4531, doi:10.1038/s41467-01806728-7 (2018).

21 Miller, H. A. et al. A Pd/C-CeO2 Anode Catalyst for High-Performance Platinum-Free Anion Exchange Membrane Fuel Cells. Angew. Chem. Int. Ed. 55, 6004-6007, doi:10.1002/anie.201600647 (2016).

22 Tian, X., Zhao, P. \& Sheng, W. Hydrogen Evolution and Oxidation: Mechanistic Studies and Material Advances. Adv. Mater. 31, e1808066, doi:10.1002/adma.201808066 (2019).

23 Cong, Y., Yi, B. \& Song, Y. Hydrogen oxidation reaction in alkaline media: From mechanism to recent electrocatalysts. Nano Energy 44, 288-303, doi:10.1016/j.nanoen.2017.12.008 (2018).

24 Strmcnik, D. et al. Improving the hydrogen oxidation reaction rate by promotion of hydroxyl adsorption. Nat. Chem. 5, 300-306, doi:10.1038/nchem.1574 (2013).

25 Dahal, A. \& Batzill, M. Graphene-nickel interfaces: a review. Nanoscale 6, 2548-2562, doi:10.1039/c3nr05279f (2014).

26 Luo, M. et al. PdMo bimetallene for oxygen reduction catalysis. Nature 574, 81-85, doi:10.1038/s41586-019-1603-7 (2019).

27 Kambe, T. et al. Redox control and high conductivity of nickel bis(dithiolene) complex pi-nanosheet: a potential organic two-dimensional topological insulator. J. Am. Chem. Soc. 136, 14357-14360, doi:10.1021/ja507619d (2014). M3(hexaiminobenzene)2 (M = Ni, Cu). J. Am. Chem. Soc. 139, 13608-13611, doi:10.1021/jacs.7b07234 (2017).

29 Hammer, B. \& Nørskov, J. K. Theoretical surface science and catalysis - calculations and concepts. Advances in Catalysis 45, 71-129, doi:10.1016/s0360-0564(02)45013-4 (2000). 
30 Doyle, R. L., Godwin, I. J., Brandon, M. P. \& Lyons, M. E. Redox and electrochemical water splitting catalytic properties of hydrated metal oxide modified electrodes. Phys. Chem. Chem. Phys. 15, 13737-13783, doi:10.1039/c3cp51213d (2013).

$31 \mathrm{Li}$, J. et al. Experimental Proof of the Bifunctional Mechanism for the Hydrogen Oxidation in Alkaline Media. Angew. Chem. Int. Ed. 56, 15594-15598, doi:10.1002/anie.201708484 (2017).

32 Jia, Q. Y., Liu, E. S., Jiao, L., Li, J. K. \& Mukerjee, S. Current understandings of the sluggish kinetics of the hydrogen evolution and oxidation reactions in base. Curr Opin Electroche 12, 209-217, doi:10.1016/j.coelec.2018.11.017 (2018).

$33 \mathrm{Li}$, J. F. et al. Shell-isolated nanoparticle-enhanced Raman spectroscopy. Nature 464, 392-395, doi:10.1038/nature08907 (2010).

34 McCrum, I. T. \& Koper, M. T. M. The role of adsorbed hydroxide in hydrogen evolution reaction kinetics on modified platinum. Nature Energy 5, 891-899, doi:10.1038/s41560020-00710-8 (2020).

35 Rebollar, L. et al. "Beyond Adsorption" Descriptors in Hydrogen Electrocatalysis. ACS Catal. 10, 14747-14762, doi:10.1021/acscatal.0c03801 (2020).

36 Giles, S. A., Yan, Y. \& Vlachos, D. G. Effect of Substitutionally Doped Graphene on the Activity of Metal Nanoparticle Catalysts for the Hydrogen Oxidation Reaction. ACS Catal. 9, 1129-1139, doi:10.1021/acscatal.8b03338 (2018).

37 Gao, L. et al. A nickel nanocatalyst within a h-BN shell for enhanced hydrogen oxidation reactions. Chem. Sci. 8, 5728-5734, doi:10.1039/c7sc01615h (2017).

38 Yang, F. et al. Enhanced HOR catalytic activity of PGM-free catalysts in alkaline media: the electronic effect induced by different heteroatom doped carbon supports. J. Mater. Chem. A 7, 10936-10941, doi:10.1039/c9ta01916b (2019).

39 Yang, Y. et al. High-Loading Composition-Tolerant Co-Mn Spinel Oxides with Performance beyond $1 \mathrm{~W} / \mathrm{cm} 2$ in Alkaline Polymer Electrolyte Fuel Cells. ACS Energy Letters 4, 1251-1257, doi:10.1021/acsenergylett.9b00597 (2019).

40 Wade, C. R. \& Dinca, M. Investigation of the synthesis, activation, and isosteric heats of $\mathrm{CO} 2$ adsorption of the isostructural series of metal-organic frameworks M3(BTC)2 (M = Cr, Fe, Ni, Cu, Mo, Ru). Dalton Trans. 41, 7931-7938, doi:10.1039/c2dt30372h (2012).

41 Sheng, W. C., Gasteiger, H. A. \& Shao-Horn, Y. Hydrogen Oxidation and Evolution Reaction Kinetics on Platinum: Acid vs Alkaline Electrolytes. J. Electrochem. Soc. 157, B1529-B1536, doi:10.1149/1.3483106 (2010).

Acknowledgments: W.N. and X.H. acknowledge the financial support of EPFL;. T.W. and Y.Y. acknowledge acknowledge the financial support from the US Department of Energy, Advanced Research Projects Agency-Energy under Award No. DE-AR0000771, DEAR0000805, DE-AR0001034, DE-AR0001149; F. H. and J.S.L. acknowledge the financial supported by European Research Council (ERC) under the European Union's Horizon 2020 research and innovation program (Starting grant: CATACOAT, No 758653) as well as the Swiss 
National Science Foundation through grant PYAPP2_15428; S.L acknowledges the Marie Skłodowska-Curie Fellowship (no. 838367).

Author contributions: W.N. designed and synthesized all the catalysts, performed electrochemical tests and characterizations; T.W. assembled the MEAs and performed the fuel cell measurements; F.H. performed the chemisorption experiments and analyzed the data with J.S.L.; A.K. performed the UPS measurements and analyzed the data with A.S.; S.L. and W.N. performed the in situ Raman experiments; L.Y. performed the four-probe conductivity measurements; W.N. and X.H. wrote the paper, with input from all the other co-authors. Y.Y. and X.H. directed the research. W.N. and T.W. contributed equally to this work. Competing interests: Authors declare no competing interests.

Data availability statement: All data are available in the main text and the supplementary information. 